\title{
VISIT TO THE ZOOLOGICAL GARDENS.
}

\author{
Director: Frank E. Beddard, M.A., F.R.S. \\ Excursion Secretary: A. C. Young, F.C.S.
}

A NUMBER of members and their friends were very kindly conducted over parts of the Gardens of the Zoological Society, on Saturday, April I2, by Prof. Beddard. The special object of the visit was to inspect the large and comprehensive collection of Ungulates now in the gardens; and it was to this group of the Mammalia, so interesting and important to the student of the palœontology of Tertiary deposits, that Prof. Beddard, in his remarks, mainly directed the attention of the visitors.

A hearty vote of thanks to the Director and the authorities, to whose courtesy the admission and entertainment of the party was due, terminated the proceedings of a very pleasant afternoon.

EXCURSION TO S.E.R. MAIN LINE WIDENING AT ELMS'IEAD CUTTING, AND TO CHISELHURST CAVES.

Saturday, April 26Th, igo2.

Directors: T. V. Holmes, F.G.S., and C. W. Osman, A.M.I.C.E. Excursion Secretary: A. C. Young, F.C.S. (Report by The DiRectors.)

TuE party, numbering between fifty and sixty, met at Grove Park Station, and at once proceeded along the railway line in the direction of Chiselhurst. The cutting north-west of the tunnel between Grove Park and Chiselhurst was soon reached, but the clear and continuous section displayed in the years 1900 and I90I had disappeared. $\Lambda$ ll that could be seen was an occasional glimpse of the basement bed of the London Clay, with a few feet of the sands and pebble bands of the underlying beds of the Oldhaven or Blackheath Series. After a few remarks from the Directors on the section lately visible there, the party took the path over the hill above the new tunnel, in the direction of Chiselhurst. After passing over the highest part of the hill, which is capped by London Clay, a deep cutting became visible towards the southeastern end of the tunnel. At the north-western end of this cutting the top of the section was more or less obscured by talus. But where clear it was seen to consist throughout of lightcoloured sand with pebble-bands, the beds, at various levels, having been consolidated into pudding stone or sandstone by calcareous cement. Except that towards the bottom the sands 